\title{
Development of a functional ingredient rich in hesperidin from citrus fruit wastes
}

\author{
Desenvolvimento de um ingrediente funcional rico em hesperidina a partir de resíduos de frutos \\ cítricos
}

Desarrollo de un ingrediente funcional rico en hesperidina de residuos de frutas cítricas

Received: 09/13/2021 | Reviewed: 09/19/2021 | Accept: 09/22/2021| Published: 09/24/2021

\author{
Camila Tomé da Cunha \\ ORCID: https://orcid.org/0000-0001-6513-9677 \\ Ceará State University, Brazil \\ E-mail: camila_tome@outlook.com \\ Andressa Fontes Oliveira \\ ORCID: https://orcid.org/0000-0002-0385-8083 \\ Ceará State University, Brazil \\ E-mail: andressafontes@hotmail.com \\ Victor Borges Fernandes \\ ORCID: https://orcid.org/0000-0003-4666-1026 \\ Ceará State University, Brazil \\ E-mail: victor.fernandes@aluno.uece.br \\ Francisca Noélia Pereira Mendes \\ ORCID: https://orcid.org/0000-0002-3872-6945 \\ Federal University of Ceará, Brazil \\ E-mail: noeliafnpm@uol.com.br \\ Ícaro Gusmão Pinto Vieira \\ ORCID: https://orcid.org/0000-0002-0576-3643 \\ Federal University of Ceará, Brazil \\ E-mail: icarogpv@uol.com.br
}

\begin{abstract}
The peels of citrus fruits contain a high concentration of bioactive compounds. Among these compounds, hesperidin stands out for its beneficial health effects. This study had the objective of evaluating the hesperidin content in peel samples of different citrus fruit and to propose the development of a functional product obtained from these peels. The peels were lyophilized and had the total flavonoids analyzed by high-performance liquid chromatography. The peels of several fruits were dried in a microwave oven and ground in a blender to obtain a homogeneous powder. This material was submitted to extraction and quantification of hesperidin. The highest concentrations were found in the 'Ponkan' tangerine, 'Murcott' tangerine and 'Navel' orange, while the lowest were found in the 'Sicilian' lemon and 'Lima' orange. The functional ingredient obtained from the ground peels after microwave drying can be used for direct consumption or to enrich food preparations.
\end{abstract}

Keywords: Functional food; Phytochemicals; Food waste; HPLC.

\section{Resumo}

As cascas de frutas cítricas contêm alta concentração de compostos bioativos. Dentre esses compostos, a hesperidina se destaca por seus efeitos benéficos à saúde. Este estudo teve como objetivo avaliar o teor de hesperidina em amostras de cascas de diferentes frutas cítricas e propor o desenvolvimento de um produto funcional obtido a partir dessas cascas. As cascas foram liofilizadas e tiveram os flavonoides totais analisados por cromatografia líquida de alta eficiência. As cascas de diversas frutas foram secas em forno de microondas e trituradas no liquidificador para obtenção de um pó homogêneo. Este material foi submetido à extração e quantificação de hesperidina. As maiores concentrações foram encontradas na tangerina 'Ponkan', na tangerina 'Murcott' e na laranja 'Baía', enquanto as menores foram encontradas no limão 'Siciliano' e na laranja 'Lima'. O ingrediente funcional obtido a partir das cascas moídas pode ser utilizado para consumo direto ou para enriquecimento de preparações alimentícias.

Palavras-chave: Alimento funcional; Compostos bioativos; Resíduos de alimentos; HPLC.

\section{Resumen}

Las cáscaras de los cítricos contienen una alta concentración de compuestos bioactivos. Entre estos compuestos, la hesperidina destaca por sus efectos beneficiosos para la salud. Este estudio tuvo como objetivo evaluar el contenido de hesperidina en muestras de piel de diferentes cítricos y proponer el desarrollo de un producto funcional obtenido de estas cáscaras. Las cáscaras se liofilizaron y se analizaron los flavonoides totales mediante cromatografía líquida de alta resolución. Las cáscaras de varias frutas se secaron en un horno de microondas y se molieron en una licuadora para obtener un polvo homogéneo. Este material se sometió a extracción y cuantificación de hesperidina. Las 
concentraciones más altas se encontraron en la mandarina "Ponkan", la mandarina "Murcott" y la naranja "Bahía", mientras que las más bajas se encontraron en el limón "Siciliano" y la naranja "Lima". El ingrediente funcional obtenido de las cáscaras molidas después del secado por microondas puede utilizarse para consumo directo o para enriquecer preparaciones alimenticias.

Palabras clave: Alimentos funcionales; Fitoquímicos; Resíduos de alimentos; HPLC.

\section{Introduction}

A diet rich in fruits is recognized as a factor that can prevent non-transmissible chronic diseases and generally protect health (Gillman, et al., 1995; He, et al., 2007; Bae, et al., 2008). Citrus fruits are among the main preferences of a large portion of consumers, attracted by the organoleptic properties, and are thus among the leading fruits cultivated in the world. They contain a wide range of nutrients, such as vitamin $\mathrm{C}$ and $\mathrm{A}$, folic acid, potassium and phosphorus, as well as fibers. Citrus fruits such as oranges, tangerines, limes and lemons have various health benefits due to their contents of bioactive substances (naringin, hesperidin, hesperetin, neohesperidin, alkaloids and hydroxamic acids), many of which belong to the flavonoids class (He, et al., 2011; Mencherini, et al., 2013; Cicero, et al., 2015; Salvo, et al., 2016; Zhou, et al., 2016; Metro, et al., 2018).

Flavonoids are produced by the secondary metabolism of plants and compose the major group of known natural products, among which are flavanones, flavones, chalcones, flavanonols, flavonols, isoflavones, flavan-3-ols and anthocyanidins (Cazarolli, et al., 2008; Coutinho, 2009). Hesperidin us a flavone found in large amounts in citrus fruits, and indeed is the main bioactive component of these fruits. Among its health benefits are treatment and prevention of obesity (Ohara et al., 2015), type II diabetes (Homayouni, et al., 2018) and cardiovascular ailments (Salden, et al., 2016), as well as action against hepatocarcinogenesis (Fernández-Bedmar, et al., 2017) and enhancement of neurocognition (Matias, et al., 2017) and capillary permeability (Garg, et al., 2001).

Because of its chemical structure, hesperidin (Fig. 1) has low solubility in water, which explains its greater concentration in the peels of citrus fruits compared to the pulp (Fernández-Bedmar, et al., 2017; Garg, et al., 2001; Nielsen, et al., 2005). In turn, the peels are the main byproduct of industrial processing of citrus fruits, and their disposal is an important source of envrionmental pollution (Wang, et al., 2008).

Figure 1. Chemical structure of hesperidin.

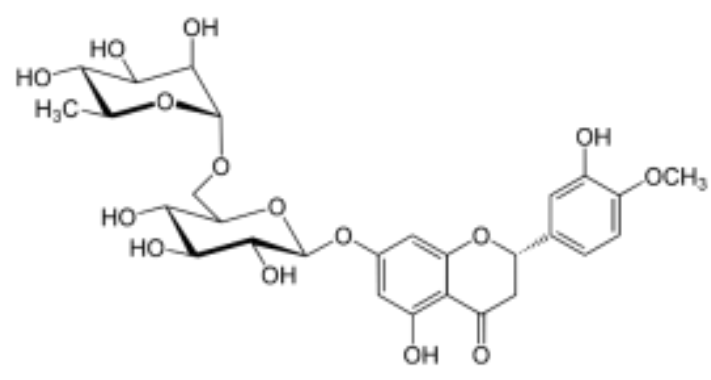

Source: Devi et al. (2015).

The peels and seeds of many fruits contain bioactive substances (Abrahao, et al., 2010), thus attracting the investigation of scientists. This composition can add value to the byproducts of fruit processing, for use as inputs in the pharmaceutical industry or as nutritional supplements and functional ingredients in other foods (Oliveira, 2014).

Although there are no recommendations for consumption of given levels of bioactive compounds, various studies have sought to determine the effect of different doses of hesperidin on human health. Nevertheless, there is a lack of data on 
the therapeutic clinical effects, dosage and bioavailability, mainly in humans (Parhiz, et al., 2015). The consumption of byproducts of processed foods is still low, due to cultural factors and social customs, meaning many consumable parts of plants that are beneficial to health go to waste (Gondim, et al., 2005).

In this context, the objective of this study was to quantify the concentration of hesperidin in the peels of various citrus fruit varieties sold supermarkets in a city in Northeast Brazil, to analyze the possibility of using these residues as a functional ingredient, based on their nutritional composition, and in particular their antioxidant activity.

\section{Methodology}

\section{Obtaining and preparing the samples}

The peels were obtained from fresh fruits sold in supermarkets in the city of Fortaleza, capital of the state of Ceará. We selected the following citrus species: 'Pera' orange (Citrus sinensis L. Osbeck var. pera), 'Lima' orange (C. sinensis L. Osbeck var. lima), 'Persian sweet lime' (C. limetticoides), 'Navel' orange (C. sinensis L. Osbeck var. baía), 'Murcott' tangerine (C. aurantium x reticulata var. mucorte), 'Clementine' (C. clementina), 'Ponkan' tangerine (C. reticulata Blanco var. poncan), 'Key lime' (C. aurantifolia), ‘Tahiti' lime (C. latifólia) and 'Sicilian' lemon (C. limon).

The fruits were manually peeled, and the peels were ground, frozen and vacuum lyophilized at $-50^{\circ} \mathrm{C}$, under $5 \mathrm{Mtorr}$ (9.67x10-5 psi) for 48 hours in a benchtop lyophilizer (Edwards, West Sussex, United Kingdom). The resulting material was stored in a hermetically sealed glass container for later analysis.

\section{Extraction of the hexane-soluble fraction (volatile and fixed oils) and total flavonoids}

The essential oils and pigments were extracted as described in the patent document (Craveiro, et al., 2009). Approximately $30 \mathrm{~g}$ of each freeze-dried and powdered sample was submitted to extraction with $800 \mathrm{~mL}$ of hexane P.A. (Saint Loius, USA) in a Soxhlet system for 24 hours. Then the total flavonoids were obtained by treating the resulting sample with $800 \mathrm{~mL}$ of methanol P.A. (Saint Loius, USA) for 24 hours. The resulting solution was concentrated under vacuum in a rotary evaporator until forming a precipitate. The concentrated material was then filtered, dried and weighed.

\section{High-performance liquid chromatography (HPLC) analysis}

High-performance liquid chromatography (HPLC) was used for quali-quantitative analysis of hesperidin in each extract obtained, using a Shimadzu (Kyoto, Japan) LC 10Avp chromatography system equipped with an LC-10ADvp pump, 20 $\mu \mathrm{L}$ loop, manual injector with fixed volume of $100 \mu \mathrm{L}$, CTO-10Avp column oven at $40^{\circ} \mathrm{C}$, SPD-M10Avp detector, and Shimpack C18 column (CLC, ODS, $150 \mathrm{~mm}$ x $4.6 \mathrm{~mm}$ ). The chromatograms were processed at $280 \mathrm{~nm}$, with run time of 20 minutes and flow of $1.2 \mathrm{~mL} / \mathrm{min}$, operating in isocratic mode, with the mobile phase composed of a 79\% acetic acid (Nuclear, São Paulo, Brazil) solution (0.025\% v/v) and 21\% HPLC-grade acetonitrile P.A (J. T. Baker, State of Mexico, Mexico) (Anagnostopoulou, et al., 2006).

The samples were prepared by dissolving $5 \mathrm{mg}$ of the methanolic extract obtained from each citrus variety in $50 \mathrm{~mL}$ of methanol (HPLC grade). Then this solution was diluted in $25 \mathrm{~mL}$ of the same solvent and a small sample $(1 \mathrm{~mL})$ was removed, filtered and injected in triplicate in the chromatograph. The hesperidin was detected by comparison between the retention times $(\mathrm{RT}=6.7 \mathrm{~min}$ ) obtained for each sample in comparison with a reference standard (hesperidin, Sigma-Aldrich, 97\% HPLC).

The hesperidin was quantified by the external standard method, with a calibration curve obtained with standard solutions with four concentrations $(3.92,0.789,0.392$ and $0.784 \mu \mathrm{g} . \mathrm{L}-1)$, injected in triplicate, with rejection of area values with variations greater than $5 \%$. After optimization of the chromatographic conditions, the method was validated as described 
in Table 1. The quantitative results were expressed in $\mathrm{mg}$ of hesperidin/100 $\mathrm{g}$ of freeze-dried peel.

Table 1. Validation of the method for quantifying hesperidin in the peels of citrus fruits.

\begin{tabular}{ll}
\hline Parameter & Value \\
\hline Limit of detection & $2.010^{-3} \mathrm{ng} \cdot \mathrm{mL}^{-1}$ \\
Limit of quantification & $2.010^{-2} \mathrm{ng} \cdot \mathrm{mL}^{-1}$ \\
Linearity $^{\dagger}$ & $\mathrm{y}=40,803 \mathrm{x}+6,087.3$ \\
Linear correlation coefficient $\left(\mathbf{R}^{2}\right)$ & 0.9989 \\
\hline
\end{tabular}

$\dagger$ Where $\mathrm{x}=$ concentration; $\mathrm{y}=$ area under peak. Source: Authors.

\section{Preparing the functional ingredient}

To prepare the functional ingredient, fruits of the varieties 'Navel' orange and 'Ponkan' tangerine were peeled and the peels were cut manually and dried in a microwave oven (Consul@) for 7 minutes at power of $100 \mathrm{kw}$. The dried peel material was then ground in a blender until forming a homogeneous powder. The objective of this preparation method was to obtain a product that is easy to prepare, so as to stimulate the consumption of citrus fruit peels. The choice of the two varieties was based on the excellent hesperidin yield and their availability for purchase.

\section{Statistical Analysis}

The statistical analysis was performed with Excel, to calculate the mean, standard deviation and coefficient of variation of the values obtained after chromatography.

\section{Results and Discussion}

Hesperidin was detected in all the citrus peel samples analyzed by HPLC, by the presence of the characteristic peak, with retention time of $6.7 \mathrm{~min}$, near that obtained by injecting the reference standard, producing the same ultraviolet (UV) absorption curve, as shown in the chromatograms presented in Figures 2 and 3.

Figure 2. (a) Chromatogram obtained by injecting the hesperidin standard at $280 \mathrm{~nm}$ and retention time of $6.7 \mathrm{~min}$. (b) UV curve of the peak at $6.7 \mathrm{~min}$.

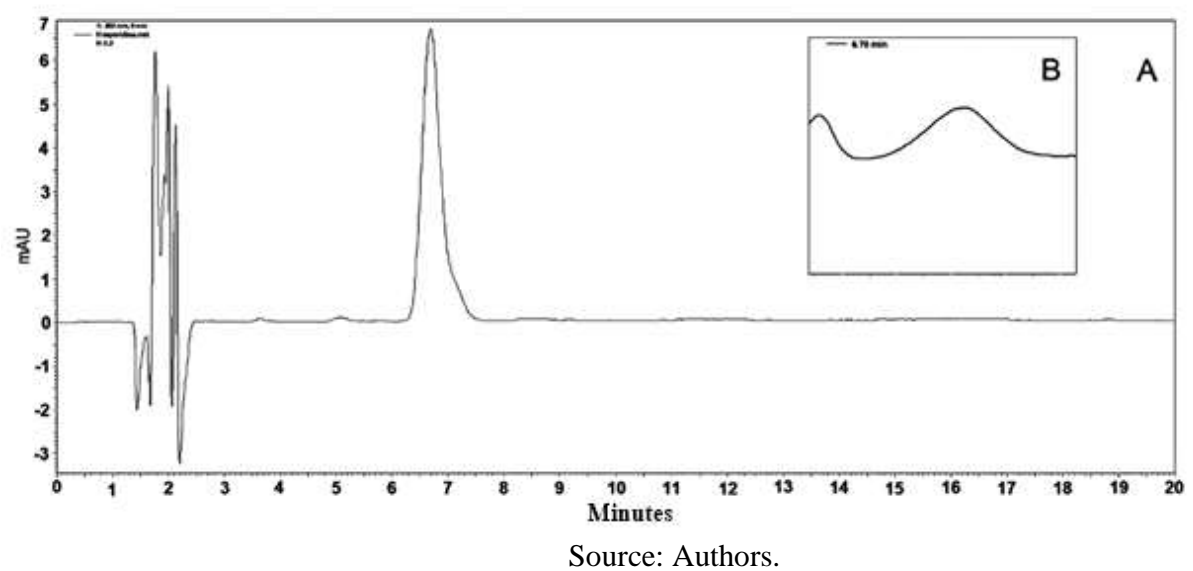


Figure 3. (a) Chromatogram obtained by injecting a sample of total flavonoids from 'Pera' orange at $280 \mathrm{~nm}$. Retention time: $6.7 \mathrm{~min}$. (b) Peak of UV curve at $6.7 \mathrm{~min}$.

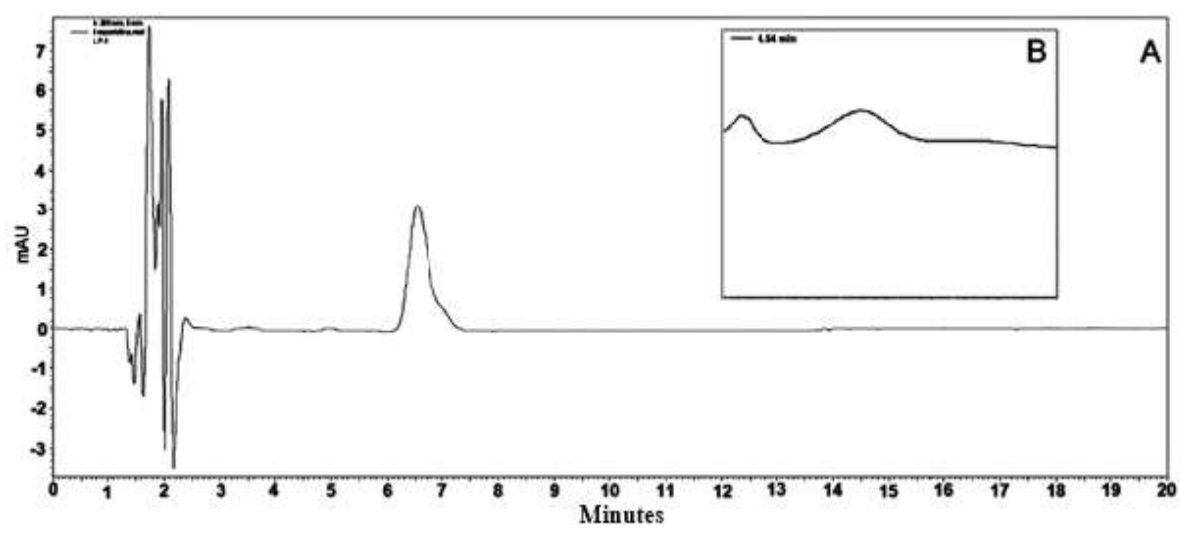

Source: Authors.

The quantification of hesperidin was carried out after the chromatographic analysis of all the samples, based on the quantitative parameter of the area under the curves obtained for the analyte in the different matrices. Comparison with the calibration curve was used to calculate the concentrations of hesperidin present in the samples of dried citrus peel, as presented in Table 2 .

Table 2. Concentration of hesperidin in $\mathrm{mg} / \mathrm{g}$ in dried peel samples of citrus fruit varieties.

\begin{tabular}{cc}
\hline Sample & $\begin{array}{c}\text { Concentration of hesperidin in } \\
\text { mg/g of dry peel }\end{array}$ \\
\hline 'Ponkan' tangerine (PT) & $21.57 \pm 0.59$ \\
'Morcott' tangerine (MT) & $20.34 \pm 1.19$ \\
'Navel' orange (NO) & $16.97 \pm 0.12$ \\
'Persian' sweet lime (PSL) & $16.68 \pm 0.43$ \\
'Pera' orange (PO) & $13.82 \pm 0.10$ \\
Clementine (C) & $13.55 \pm 0.16$ \\
'Key lime' (KL) & $12.77 \pm 0.13$ \\
'Tahiti' lime (TL) & $8.07 \pm 0.23$ \\
'Lima' orange (LO) & $6.59 \pm 0.05$ \\
'Sicilian' lemon (SL) & $4.78 \pm 0.20$ \\
'Navel' orange by microwave drying only & $13.28 \pm 0.06$ \\
(NOM) & \\
\hline (PTM) & $23.10 \pm 0.10$ \\
\hline
\end{tabular}

The results are expressed as mean \pm standard deviation $(\mathrm{n}=3)$. Source: Authors.

Hesperidin is the main flavonoid contained in oranges, lemons and limes (Garg, et al., 2001). In this study, the highest concentrations of hesperidin (in $\mathrm{mg} / \mathrm{g}$ of freeze-dried peel) were obtained in the varieties PT (21.57 \pm 0.59$)$, MT (20.34 \pm 1.19 ), NO (16.97 \pm 0.12$)$ and PSL (16.68 \pm 0.43$)$ respectively. Curiously, the 'Ponkan' tangerine is the tangerine variety consumed 
most by brazilians (Pio, et al., 2005). In turn, the lowest concentrations were found in the varieties LO (4.78 \pm 0.20$)$ and SL $(6.59 \pm 0.05)$.

Comparison of the hesperidin concentrations measured in the samples obtained in the two drying methods (microwave and lyophilization) showed NOM values of $13.28 \pm 0.06$ and NO of $16.97 \pm 0.12 \mathrm{mg} / \mathrm{g}$, and PTM of $23.10 \pm 0.11 \mathrm{mg} / \mathrm{g}$, but PT of $21.57 \pm 0.59$. The statistical analysis showed that the two drying methods produced highly homogeneous results (coefficient of variation near zero). Xu and colleagues tested various methods to dry tangerine peels and concluded that the infrared method was most efficient to preserve the nutraceutical components and also to optimize the time (Xu, et al., 2017). However, the method proposed here, of microwave drying, produced levels near those obtained via lyophilization, thus having the advantage of lower cost and easier availability of equipment.

In the peels of hybrid citrus varieties grown in China, the hesperidin concentrations varied from 0.837 to $7.995 \mathrm{mg} / \mathrm{g}$ (He, et al., 2011). Among them, the highest concentration was found in the hybrid obtained from crossing Citrus unshiu Marc. x Citrus clementina Hort ex Tanaka, a result similar to that for TL in this work $(8.07 \mathrm{mg} / \mathrm{g})$. The values found in this study are greater than those in the study by He and colleagues (2011), probably due to the differences in methods and varieties of the species.

Another study, conducted in South Korea, analyzed the nutritional content of different citrus species grown in that country, and found the highest hesperidin levels in the peel of the 'Yuzu' variety (Citrus junos Sieb. Ex Tanaka) (7.49mg/g), followed by the tangerine (Citrus sunki Hort. ex Tanaka) $(6.39 \mathrm{mg} / \mathrm{g}$ ) and orange (Citrus sinensis) (4.23mg/g) (Assefa, et al., 2017). When comparing the peel with the respective pulp, the authors obtained levels 1.91 to 4.40 times higher in the peels. These findings support the importance of investigating the composition of citrus peels and their relevance to the food industry and for consumption as a source of bioactives compounds.

In Brazil, data about the concentration of hesperidin in citrus fruits are scarce (Arabbi, et al., 2004). A study carried out in São Paulo applied HPLC to analyze the hesperidin content in the peel of citrus fruits sold in the city. The authors concluded that methanol was the best solvent to extract hesperidin (highest yield). Among the varieties analyzed, the 'Navel' orange obtained the highest yield $(37.84 \mathrm{mg} / \mathrm{g})$, followed by the 'Seleta' orange (36.36 mg/g) and 'Ponkan' tangerine $(29.10 \mathrm{mg} / \mathrm{g})$. The lowest levels were obtained for the 'Persian' sweet lime (3.30 mg/g) and 'Morcott' tangerine (3.60 mg/g) In this study, the values of the varieties with best yield are similar to those found by Pereira (Pereira, et al., 2017).

A study carried out with patients suffering from type 2 diabetes tested supplementation of $500 \mathrm{mg} / \mathrm{day}$ of hesperidin for 6 weeks, and found a significant percentage difference in the systolic, diastolic and mean arterial pressure, besides reduction of inflammatory markers such as tumor necrosis factor alpha, interleukin 6 and C-reactive protein in comparison with the placebo group. Based on these results, the authors suggested that hesperidin can have anti-hypertensive and antiinflammatory effects in patients with type 2 diabetes (Homayounu, et al., 2018).

Based on that study, to obtain the hesperidin dose of $500 \mathrm{mg}$ would require supplementation of $23,2 \mathrm{~g}$ of dried 'Ponkan' tangerine peel (about 1 tablespoon) and 29,5 g of dried 'Navel' orange peel (roughly one and a half tablespoon). This product could be added in the preparation of many foods, such as breads, cakes, cookies and also smoothies.

A study evaluating the consumer acceptance of bread prepared with substitution of fat with $2.5 \%$ orange peel fiber combined with the use of $30 \mathrm{ppm}$ of the enzyme $\alpha$-amylase found an acceptance index of about $80 \%$, indicating the effectiveness of this form of using citrus byproducts (Stoll, et al., 2015). Another study showed that flour made from orange bagasse from industrial juice extraction presented sufficient yield for preparation of enriched bread and also obtained acceptance near $80 \%$ (Storrer, 2017). 


\section{Conclusion}

In the present study, the peel of all the citrus varieties analyzed had good hesperidin yields, with the best being 'Ponkan' tangerine, Morcott tangerine, 'Navel' orange and 'Persian' sweet lime, all of which are good sources of the substance.

The process of drying and grinding the peel can be carried out simply and inexpensively with a microwave oven and blender. The product obtained can be consumed directly, added to nutraceutical preparations or included as an active ingredient in other foods.

Therefore, it is necessary to stimulate the consumption of the entire citrus fruit, especially the peel, due to the presence of high levels of bioactives compounds. However, further studies are necessary to evaluate the bioavailability of these nutrients in fruit peels in vivo.

\section{Acknowledgments}

We are grateful for the support of the Technological Development Park of Ceará Federal University.

\section{References}

Abrahão, S. A., Pereira, R. G. F. A., Duarte, S. M. S., Lima, A. R., Alvarenga, D. J., \& Ferreira, E. B. (2010). Compostos bioativos e atividade antioxidante do café (Coffea arabica L.). Ciência e Agrotecnologia, 34(2). https://doi.org/10.1590/s1413-70542010000200020

Anagnostopoulou, M. A., Kefalas, P., Papageorgiou, V. P., Assimopoulou, A. N., \& Boskou, D. (2006). Radical scavenging activity of various extracts and fractions of sweet orange peel (Citrus sinensis). Food Chemistry, 94(1). https://doi.org/10.1016/j.foodchem.2004.09.047

Arabbi, P. R., Genovese, M. I., \& Lajolo, F. M. (2004). Flavonoids in Vegetable Foods Commonly Consumed in Brazil and Estimated Ingestion by the Brazilian Population. Journal of Agricultural and Food Chemistry, 52(5). https://doi.org/10.1021/jf0499525

Assefa, A. D., Saini, R. K., \& Keum, Y. S. (2017). Fatty acids, tocopherols, phenolic and antioxidant properties of six citru s fruit species: a comparative study. Journal of Food Measurement and Characterization, 11(4). https://doi.org/10.1007/s11694-017-9546-X

Bae, J. M., Lee, E. J., \& Guyatt, G. (2008). Citrus fruit intake and stomach cancer risk: A quantitative systematic review. Gastric Cancer, 11(1). https://doi.org/10.1007/s10120-007-0447-2

Cazarolli, L., Zanatta, L., Alberton, E., Bonorino Figueiredo, M. S., Folador, P., Damazio, R., \& Barreto Silva, F. R. (2008). Flavonoids: Prospective Drug Candidates. Mini-Reviews in Medicinal Chemistry, 8(13). https://doi.org/10.2174/138955708786369564

Cicero, N., Corsaro, C., Salvo, A., Vasi, S., Giofré, S. V., Ferrantelli, V., \& Dugo, G. (2015). The metabolic profile of lemon juice by proton HR-MAS NMR: The case of the PGI Interdonato Lemon of Messina. Natural Product Research, 29(20), 1894-1902. https://doi.org/10.1080/14786419.2015.1012166

Coutinho, M. A. S., Muzitano, M. F., \& Costa, S. S. (2009). Flavonoids: Potential therapeutic agents for the inflammatory process. Revista Virtual de Química, 1(3). https://doi.org/10.5935/1984-6835.20090024

Craveiro, A., Craveiro, A., Pinto, Í., \& Mendes, F. (2009). Processo de obtenção de bioflavonóides cítricos, notadamente hesperidina, a partir de polpa cítrica peletizada e resíduos de frutas cítricas. https://www.escavador.com/patentes/351341/processo-de-obtencao-de-bioflavonoides-citricos-notadamentehesperidina-a

Devi, K. P., Rajavel, T., Nabavi, S. F., Setzer, W. N., Ahmadi, A., Mansouri, K., \& Nabavi, S. M. (2015). Hesperidin: A promising anticancer agent from nature. Industrial Crops and Products, 76, 582-589. https://doi.org/10.1016/j.indcrop.2015.07.051

Fernández-Bedmar, Z., Anter, J., Alonso-Moraga, A., Martín de las Mulas, J., Millán-Ruiz, Y., \& Guil-Luna, S. (2017). Demethylating and antihepatocarcinogenic potential of hesperidin, a natural polyphenol of Citrus juices. Molecular Carcinogenesis, 56(6). https://doi.org/10.1002/mc.22621

Garg, A., Garg, S., Zaneveld, L. J. D., \& Singla, A. K. (2001). Chemistry and pharmacology of the Citrus bioflavonoid hesperidin. Phytotherapy Research. https://doi.org/10.1002/ptr.1074

Gillman, M. W., Cupples, L. A., Posner, B. M., Gagnon, D., Ellison, R. C., Castelli, W. P., \& Wolf, P. A. (1995). Protective Effect of Fruits and Vegetables on Development of Stroke in Men. JAMA: The Journal of the American Medical Association, $273(14)$, 1113-1117. https://doi.org/10.1001/jama.1995.03520380049034

Gondim, J. A. M., Moura, M. de F. V., Dantas, A. S., Medeiros, R. L. S., \& Santos, K. M. (2005). Composição centesimal e de minerais em cascas de frutas. Ciência e Tecnologia de Alimentos, 25(4). https://doi.org/10.1590/s0101-20612005000400032

He, D., Shan, Y., Wu, Y., Liu, G., Chen, B., \& Yao, S. (2011). Simultaneous determination of flavanones, hydroxycinnamic acids and alkaloids in citrus fruits by HPLC-DAD-ESI/MS. Food Chemistry, 127(2). https://doi.org/10.1016/j.foodchem.2010.12.109 
He, F. J., Nowson, C. A., Lucas, M., \& MacGregor, G. A. (2007). Increased consumption of fruit and vegetables is related to a reduced risk of coronary heart disease: Meta-analysis of cohort studies. Journal of Human Hypertension, 21(9), 717-728. https://doi.org/10.1038/sj.jhh.1002212

Homayouni, F., Haidari, F., Hedayati, M., Zakerkish, M., \& Ahmadi, K. (2018). Blood pressure lowering and anti-inflammatory effects of hesperidin in type 2 diabetes; a randomized double-blind controlled clinical trial. Phytotherapy Research, 32(6). https://doi.org/10.1002/ptr.6046

Matias, I., Diniz, L. P., Buosi, A., Neves, G., Stipursky, J., \& Gomes, F. C. A. (2017). Flavonoid hesperidin induces synapse formation and improves memory performance through the astrocytic TGF-ß1. Frontiers in Aging Neuroscience, 9(JUN). https://doi.org/10.3389/fnagi.2017.00184

Mencherini, T., Campone, L., Piccinelli, A. L., García Mesa, M., Sánchez, D. M., Aquino, R. P., \& Rastrelli, L. (2013). HPLC-PDA-MS and NMR characterization of a hydroalcoholic extract of citrus aurantium L. Var. amara Peel with antiedematogenic activity. Journal of Agricultural and Food Chemistry, 61(8). https://doi.org/10.1021/jf302815t

Metro, D., Tardugno, R., Papa, M., Bisignano, C., Manasseri, L., Calabrese, G., \& Cicero, N. (2018). Adherence to the Mediterranean diet in a Sicilian student population. Natural Product Research, 32(15). https://doi.org/10.1080/14786419.2017.1402317

Nielsen, I. L. F., Chee, W. S. S., Poulsen, L., Offord-Cavin, E., Rasmussen, S. E., Frederiksen, H., \& Williamson, G. (2006). Bioavailability is improved by enzymatic modification of the citrus flavonoid hesperidin in humans: A randomized, double-blind, crossover trial. Journal of Nutrition, 136(2), 404-408. https://doi.org/10.1093/jn/136.2.404

Ohara, T., Muroyama, K., Yamamoto, Y., \& Murosaki, S. (2016). Oral intake of a combination of glucosyl hesperidin and caffeine elicits an anti-obesity effect in healthy, moderately obese subjects: A randomized double-blind placebo-controlled trial. Nutrition Journal, 15(1). https://doi.org/10.1186/s12937016-0123-7

Oliveira, L. M. N. (2014). Quantificação de rutina, atividades antioxidante e antimicrobiana de extratos de polpas e subprodutos de frutas tropicais. Universidade Federal do Ceará. Retrieved from https://ppgcta.ufc.br/wp-content/uploads/2018/08/leilanne-marcia-nogueira-oliveira.pdf

Parhiz, H., Roohbakhsh, A., Soltani, F., Rezaee, R., \& Iranshahi, M. (2015). Antioxidant and anti-inflammatory properties of the citrus flavonoids hesperidin and hesperetin: An updated review of their molecular mechanisms and experimental models. Phytotherapy Research. https://doi.org/10.1002/ptr.5256

Pereira, R. M. S., López, B. G. C., Diniz, S. N., Antunes, A. A., Moreno Garcia, D., Rocha Oliveira, C., \& Marcucci, M. C. (2017). Quantification of Flavonoids in Brazilian Orange Peels and Industrial Orange Juice Processing Wastes. Agricultural Sciences, 08(07). https://doi.org/10.4236/as.2017.87048

Pio, R. M., Figueiredo, J. O., Stuchi, E. S., \& Cardoso, S. A. B. (2005). Variedades copas. In Mattos Junior, D., Negri, J. D., Pio, R. M., \& Pompeu Junior, J (Eds.), Citros (pp. 37-60). Cordeirópolis: Centro APTA Citros Sylvio Moreira.

Salden, B. N., Troost, F. J., De Groot, E., Stevens, Y. R., Garcés-Rimón, M., Possemiers, S., \& Masclee, A. A. (2016). Randomized clinical trial on the efficacy of hesperidin $2 \mathrm{~S}$ on validated cardiovascular biomarkers in healthy overweight individuals1,2. American Journal of Clinical Nutrition, 104(6). https://doi.org/10.3945/ajen.116.136960

Salvo, A., Bruno, M., La Torre, G. L., Vadalà, R., Mottese, A. F., Saija, E., \& Dugo, G. (2016). Interdonato lemon from Nizza di Sicilia (Italy): chemical composition of hexane extract of lemon peel and histochemical investigation. Natural Product Research, 30(13). https://doi.org/10.1080/14786419.2015.1115999

Stoll, L., Flôres, S. H., \& Silveira Thys, R. C. (2015). Citrus peel fiber and its application as a fat substitute in loaf brad. Citrus Peel Fiber and Its Application as a Fat Substitute in Loaf Brad, 45(3). https://doi.org/10.1590/0103-8478cr20131503

Storrer, D.; Meireles, K. H.; Perly, M. D.; Lima, R. da S.; \& Mattanna, P. (2017). Desenvolvimento de pão com adição de farinha de bagaço de laranja: análises sensoriais, físico-químicas e microbiológicas. Biociências, Biotecnologia e Saúde, 9(18), 43-50.

Wang, Y. C., Chuang, Y. C., \& Hsu, H. W. (2008). The flavonoid, carotenoid and pectin content in peels of citrus cultivated in Taiwan. Food Chemistry, 106(1). https://doi.org/10.1016/j.foodchem.2007.05.086

Xu, M., Tian, G., Zhao, C., Ahmad, A., Zhang, H., Bi, J., \& Zheng, J. (2017). Infrared Drying as a Quick Preparation Method for Dried Tangerine Peel. International Journal of Analytical Chemistry, 2017. https://doi.org/10.1155/2017/6254

Zhou, Y., Zheng, J., Li, Y., Xu, D. P., Li, S., Chen, Y. M., \& Li, H. Bin. (2016). Natural polyphenols for prevention and treatment of cancer. Nutrients. https://doi.org/10.3390/nu8080515 